\title{
Clonal architecture in an intertidal bed of the dwarf eelgrass Zostera noltii in the Northern Wadden Sea: persistence through extreme physical perturbation and the importance of a seed bank
}

\author{
Andreas M. Zipperle $\cdot$ James A. Coyer · \\ Karsten Reise - Eelo Gitz • Wytze T. Stam • \\ Jeanine L. Olsen
}

Received: 12 January 2009/ Accepted: 18 June 2009/Published online: 5 July 2009

(c) The Author(s) 2009. This article is published with open access at Springerlink.com

\begin{abstract}
Genotypic structure and temporal dynamics of the dwarf seagrass, Zostera noltii, were studied in an intertidal meadow that has persisted since prior to 1936 near the Wadden Sea island of Sylt. Samples were collected from two $10 \times 10 \mathrm{~m}$ plots separated by $250 \mathrm{~m}$ from May 2002 to June 2005 and from four $1 \times 1 \mathrm{~m}$ plots from June 2003 to September 2004. All the samples were genotyped with nine microsatellite loci. No genotypes were shared between the plots separated by $250 \mathrm{~m}$. Genetic diversity was higher in the Wadden Sea than in the other regions of its geographic range. The average clone size (genets) (SD) in the two plots was $1.38(0.26)$ and 1.46 $(0.4) \mathrm{m}^{2}$, respectively, with a range up to $9 \mathrm{~m}^{2}$ and $<20 \%$ persisted for $>4$ years. A high genetic and genotypic diversity was maintained by annual recruitment of seedlings despite a dramatic decrease in ramet density that coincided with the severe heat stress event of 2003. Finescale $\left(1 \mathrm{~m}^{2}\right)$ analysis suggested that extensive loss of seagrass cover precluded space competition among the genets, while a persistent seed bank prevented local extinction. Long-term persistence of $Z$. noltii meadows in the intertidal Wadden Sea was achieved by high genet turnover and frequent seedling recruitment from a seed bank, in contrast
\end{abstract}

Communicated by T. Reusch.

A. M. Zipperle $(\bowtie) \cdot$ J. A. Coyer · E. Gitz ·

W. T. Stam - J. L. Olsen

Department of Marine Benthic Ecology and Evolution,

Centre for Ecological and Evolutionary Studies,

Biological Centre, University of Groningen,

Kerklaan 30, 9750 AA Haren, The Netherlands

e-mail: A.Zipperle@web.de

K. Reise

Alfred Wegener Institute for Polar and Marine Research, Wadden Sea Station Sylt, 25992 List, Germany to the low diversity observed in large and long-living clones of $Z$. noltii and other seagrasses in subtidal habitats.

\section{Introduction}

The dwarf eelgrass, Zostera noltii, is the most important seagrass in the sandy to muddy intertidal of the NE Atlantic, where it forms meadows spanning tens to thousands of square meters in size (Fig. 1). Some meadows consist of several distinct genets (genetic individuals or clones), whereas others are comprised primarily of a dominant genet with high numbers of ramets (morphological individuals arising from vegetative reproduction sensu Harper 1977). Clone size and number are important measures for reproductive efficiency of seagrasses in general, as limited pollen dispersal, combined with large clone sizes and few neighboring clones, may reduce the outcrossing potential within meadows (Barrett and Harder 1996; Charpentier 2001; Reusch 2001a). In the self-compatible genus Zostera, limited outcrossing increases the rate of inbreeding and may lead to inbreeding depression and degradation of population fitness (Ellstrand and Elam 1993; Reusch 2001a; Hämmerli and Reusch 2003). Clone size and density also directly affect recruitment success from seeds through space and resource competition, and hence genetic and genotypic diversity (Eriksson 1993). Consequently, persistence of extensive and locally adapted genets can lead to a reduction of evolutionary potential to changing environmental conditions (Silvertown and Charlesworth 2001; Hämmerli and Reusch 2002).

Determination of clonal or patch architecture requires variable molecular markers such as microsatellites, which provide the only reliable means of distinguishing genets (clones) among the sea of ramets (shoots) (Reusch 2001b; 
Fig. 1 Study site. a Island of Sylt (white square) in the Northern Wadden Sea. b List tidal basin with study site (black square) in Königshafen off the northern tip of the island. c Z. noltii meadow in Königshafen: c1 1936, c2 2003 and c32004 after the large decline. Seagrass bed boundaries are outlined. Locations of Plots 1 and 2 are indicated in $\mathbf{c 2}$ and $\mathbf{c 3}$ (black dots). (Aerial photographs c1-3: AWI-Bremerhaven, Germany)
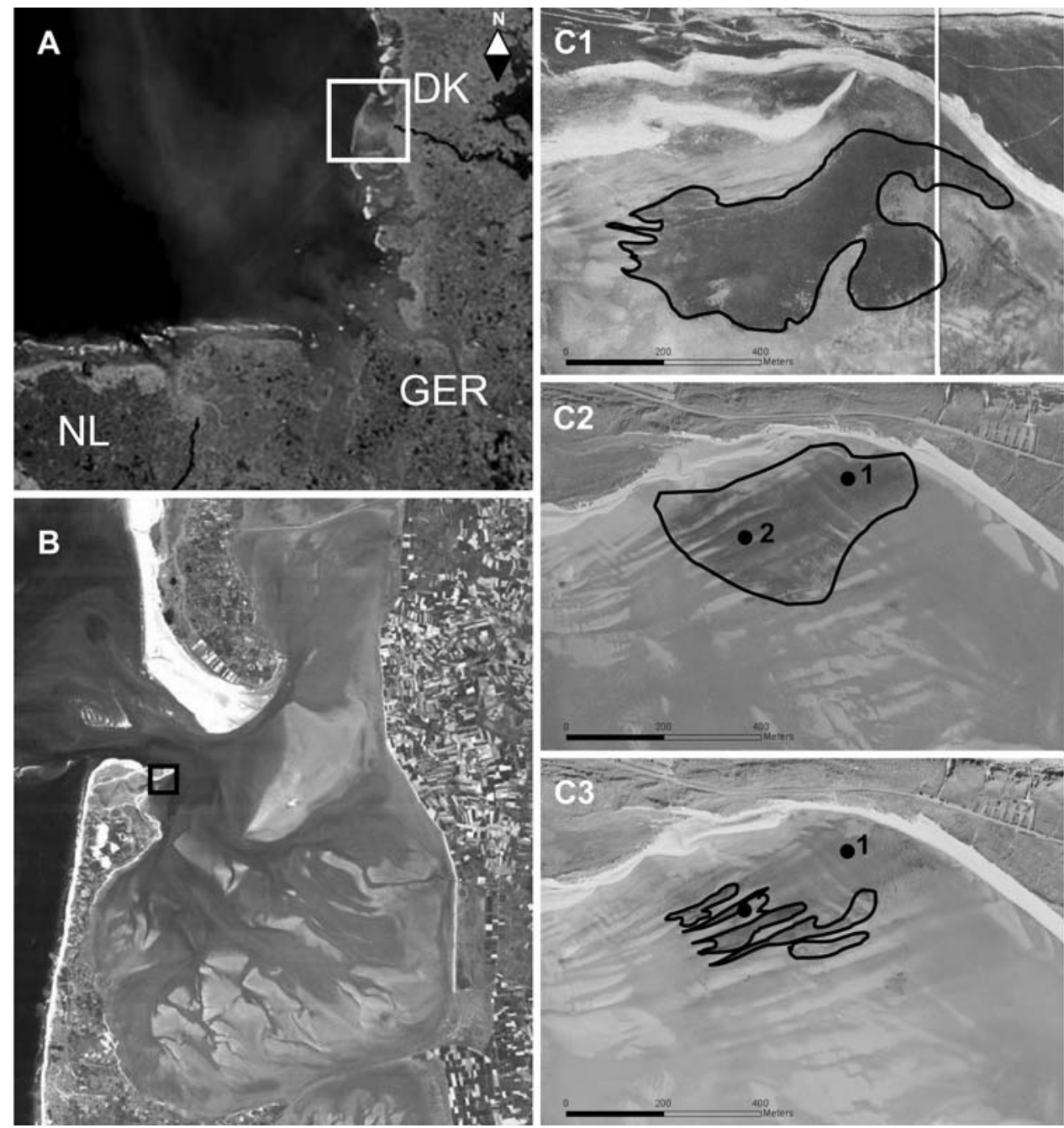

Arnaud-Haond et al. 2005). Molecular population genetic studies on several seagrass species have not only uncovered clonal structure, but revealed patterns of gene flow and population connectivity, neighborhood size, local adaptation, and the mating system (reviewed in Waycott et al. 2006; Procaccini et al. 2007), thus providing a snapshot of pattern and process at the landscape scale.

Temporal studies of seagrass clonal architecture, however, are not common, as the natural genet longevity of the most intensively studied large seagrass species (some Zostera marina, most Posidonia australis, and all Posidonia oceanica populations) ranges from decades to centuries or even millennia (Waycott 1995; Reusch et al. 1999; Ruggiero et al. 2002). To our knowledge, no study has examined temporal architectural changes of seagrass genets in a fixed area for more than 1 year.

An important component of temporal stability of plant populations is the presence/absence of a seed bank. Seed banks constitute reservoirs of genetic and genotypic diversity in established populations and may enhance recovery after population disturbance. Furthermore, recruitment from a seed bank can strongly influence population structure and genotypic diversity (Koch et al. 2003; Barrett et al. 2005; Greve et al. 2005). Seeds of Z. noltii are produced annually through subaquatic pollination of protogynous, hermaphroditic flowers. The four to six male and four to six female flowers are combined in a single spathe and release four to six negatively buoyant seeds (den Hartog 1970). Seeds enter the seed bank either directly upon release or after dispersal. While seeds typically are dispersed on the scale of a few meters (Orth et al. 1994; Ruckelshaus 1996), seeds may be more widely dispersed via floating spathes or rafting shoots of $Z$. noltii, thereby ensuring gene flow among distant populations (Coyer et al. 2004a; Erftemeijer et al. 2008) (Reusch et al. 2002; Ferber et al. 2008 for Z. marina).

Seed banks of $Z$. noltii persist for at least 3 years near the island of Sylt in the northern Wadden Sea and contribute up to $20 \%$ of the annual new recruitment (Zipperle et al. 2009). Therefore, an established meadow or large 
patch of Z. noltii could persist more or less indefinitely and indeed, decades-old meadows are known (Nienburg 1927; Wohlenberg 1935; Reise and Kohlus 2008). However, even large meadows wax and wane over the course of years (Philippart and Dijkema 1995; Zipperle, personal observation). Meadow persistence depends in part on large-scale stochastic physical factors such as the direct effects of increased hydrodynamics due to storms (Schanz and Asmus 2003), or indirectly by sediment mobility (burial, erosion) (Hemminga and Duarte 2000; Cabaço and Santos 2007; Reise and Kohlus 2008), as well as fine-scale biological disturbances associated with grazing by waterfowl (Jacobs et al. 1981; Nacken and Reise 2000). Intrinsic instability of $Z$. noltii patches also may be caused by a demographic factor. For example, once a few large clones have achieved dominance (the closely spaced ramets exhibit phalanx growth, Brun et al. 2006), the low genotypic/clonal diversity may render them more susceptible to new stress events.

In order to gain insight into the ecological and evolutionary implications of temporal changes in the large- and fine-scale genetic and genotypic composition of seagrass meadows, an intertidal meadow of $Z$. noltii was repeatedly mapped at two permanent plots at two spatial scales over a 4-year period. We examined: (1) spatial and temporal stability of meadow composition, (2) the relative importance of sexual/clonal input, and (3) the importance of a seed bank in maintaining genotypic diversity through physical perturbations.

\section{Materials and methods}

Study site and sampling

The study was conducted within an intertidal meadow of Z. noltii in the shallow bay of Königshafen on the island of Sylt, Germany $\left(55^{\circ} 2^{\prime} \mathrm{N}, 008^{\circ} 25^{\prime} \mathrm{E}\right)$ (Fig. 1). The semidiurnal tides (mean tidal range is $1.8 \mathrm{~m}$ ) leave the meadow exposed for $6-8 \mathrm{~h}$ during the low-tide period and covered with a mean water depth of $0.5 \mathrm{~m}$ during high tide. Largescale mapping of clonal architecture was determined in two permanent $10 \times 10 \mathrm{~m}$ plots, separated by $250 \mathrm{~m}$ (Fig. 1 : Plots 1 and 2). Samples were collected at the start of growing season (May/June) and at the end of growing season (September) over seven time points from May 2002 through June 2005.

Sampling for genotyping analysis followed the method of Coyer et al. (2004a) and entailed removal of leaf tissue (adult shoot or whole seedling) from plants at the center of each $1-\mathrm{m}^{2}$ subplot for a maximum of 100 samples at each time point. If no plant was present within a $10-\mathrm{cm}$ radius around the center of the subplot, no sample was collected.

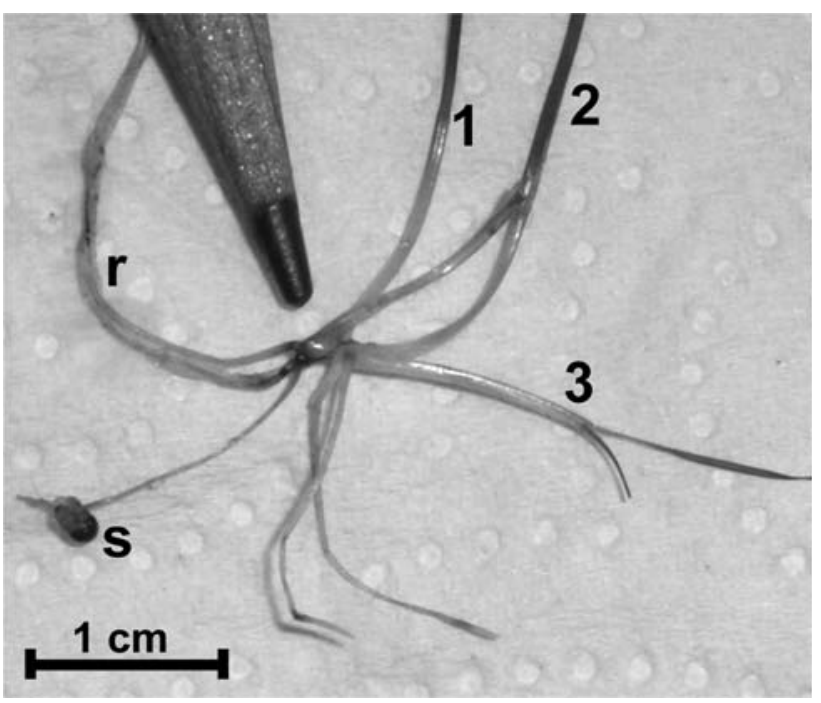

Fig. 2 Vegetative propagating Zostera noltii seedling in June. Attached seed, three vegetative shoots (1-3), and roots $(r)$ are visible. Elongated rhizome internodes are lacking

Fine-scale mapping was determined in four $1-\mathrm{m}^{2}$ subplots (quad 1-4) selected randomly within Plot 1 . Samples were collected at four time points in May and September of 2003 and 2004. Each of the four $1-\mathrm{m}^{2}$ subplots was further subdivided into $0.2 \mathrm{~m} \times 0.2 \mathrm{~m}$ quadrats, and one sample was taken from the center of each quadrat for a maximum of 25 samples. Again, if no plant was present in a $10-\mathrm{cm}$ radius around the center of a quadrat then no sample was taken. All plant material was stored in silica crystals. Seagrass density was estimated as percent-cover at low tide at the time of plant collection. Seedlings, identified by the emerging caulicle and/or the still attached seed as described by Zipperle et al. (2009), often were collected from the center of a subplot/quadrat during the early growth season (June 2004, 2005). Sampled seedlings displayed only restricted vegetative propagation in June (Fig. 2).

DNA extraction, microsatellite amplification and genotyping

Five mg of plant tissue was pulverized with a Retsch Mixer Mill MM 301 (Qiagen) and DNA was extracted following the protocol of Elphinstone et al. (2003). Nine microsatellite loci (Coyer et al. 2004b) were amplified as three triplets (plex-1: ZnB1, ZnH10 and ZnB3; plex-2: ZnB8, ZnH8 and ZnD6; plex-3: ZnE7, ZnF8 and ZnF11) using multiplex PCR in $20 \mu \mathrm{l}$ reactions $\left(2 \mathrm{mM} \mathrm{MgCl}_{2}, 0.2 \mathrm{mM}\right.$ dNTPs, 0.5 U Taq (Promega), 0.01\% bovine serum albumin, $1 \times$ reaction buffer $(10 \mathrm{mM}$ Tris $\mathrm{HCl}, 50 \mathrm{mM} \mathrm{KCl}$, $0.1 \%$ Triton X-100,) (Zipperle et al. 2009). PCR reaction conditions were the same for each primer triplet: initial denaturation $3^{\prime}$ at $94^{\circ} \mathrm{C}$, followed by 35 cycles of $40 \mathrm{~s}$ at 
$94^{\circ} \mathrm{C}, 40 \mathrm{~s}$ at $57.5^{\circ} \mathrm{C}$ and $40 \mathrm{~s}$ at $72^{\circ} \mathrm{C}$, with a final extension step of $10 \mathrm{~min}$ at $72^{\circ} \mathrm{C}$. Multiplexed primer triplets were visualized by gel electrophoresis (ABI 377 gene analyzer, Applied Biosystems) and scored against an internal lane standard (ROX 350, Applied Biosystems) using the GENSCAN software (Applied Biosystems).

\section{Data analysis}

Probabilities of identity by chance $\left(P_{\text {sex }}\left(F_{\text {IS }}\right)\right)$ were calculated for each sample to avoid false assignment of individual shoots (ramets) sharing the same multilocus genotype (MLG) by chance (GenClone 2.0; Arnaud-Haond and Belkhir 2007) to the same genet (clone). $P_{\text {sex }}\left(F_{\text {IS }}\right)$ accounts for departure from Hardy-Weinberg and provides the most conservative estimates of clonal identity (ArnaudHaond et al. 2007). Clone maps were generated with GenClone 2.0 (Arnaud-Haond and Belkhir 2007) using $x y$-coordinates of individual samples collected within the $10 \times 10 \mathrm{~m}$ plots and the four $1-\mathrm{m}^{2}$ subplots. GenClone 2.0 also assessed genetic and genotypic diversity $(R)$ for each sampling. $R$ was calculated as $R=G / N$; where $G$ is the number of genets present and $N$ is the number of ramets sampled.

The genets were tracked from May 2002 through June 2005 in the $10 \times 10 \mathrm{~m}$ plots to estimate their survival time and mean size. Only the genets found on multiple occasions were used to estimate genet longevity, since they were considered the dominant genets within the quadrat. The mean genet size (per plot) of Z . noltii was estimated by averaging sizes of genets found multiple times for each sampling date and calculating the grand mean over all samplings. A minimum estimate of genet survival was achieved by averaging the survival times of individual genets in the study period. Genotypic diversity $(R)$ and genetic diversity were calculated for each sampling date (GenClone 2.0) (Arnaud-Haond and Belkhir 2007). Genetic diversity was estimated as allelic richness $\left(N_{c}\right)$ normalized to a sample size of 28. Fine-scale clone maps of the $1-\mathrm{m}^{2}$ subplots were used to estimate the mean number of genets $\mathrm{m}^{-2}$ by calculating the mean over quad $1-4$ for individual sampling dates. $R$ was calculated for each quadrat individually for all sampling dates.

\section{Results}

Large-scale clonal architecture $\left(100 \mathrm{~m}^{2}\right)$

Seagrass cover ranged from 50 to $100 \%$ in 2002 and 2003 and declined to $<10 \%$ in 2004 and $<1 \%$ by the end of the study in June 2005 (Fig. 3, 4). Ramets sampled from Plot $1(n=570)$ and Plot $2(n=419)$ revealed 392 and 272 genets, respectively; of these, 41 and 44 were found more than one time (Fig. 3). Several genets (Plot 1, $n=39$; Plot 2, $n=41$ ) found in May 2002 were tracked for growth and survival. Estimates of $P_{\text {sex }}\left(F_{\text {IS }}\right)$ confirmed clonal identity for all ramets sharing the same MLG on both the large- and fine-scale. The mean genet size (SD) in Plot $1\left(1.46[0.4] \mathrm{m}^{2}\right)$ was equivalent to Plot $2(1.38$ [0.26] $\left.\mathrm{m}^{2}\right)$ ( $t$ test; $\left.p=0.34\right)$. However, genets exceeding $3 \mathrm{~m}^{2}$ were restricted to 2002 and 2003 in both plots (Fig. 3). The $1-\mathrm{m}^{2}$ size class was dominant; but genet sizes ranged up to $9 \mathrm{~m}^{2}$.

The mean genet survival time (SD) was $2.1(0.61)$ years in Plot 1 , significantly less than in Plot 2 (3.14 [0.9] years) ( $t$ test; $p<0.001)$. Only one genet $(2.4 \%)$ survived for 4 years in Plot 1 while $18(41 \%)$ genets survived the study period in Plot 2 (Figs. 3, 4). Genotypic diversity $(R)$ and allelic richness remained high throughout the study period and invariant among plots. Average $R$ was 0.84 in both Plot 1 and Plot 2 (ranging from 0.64 to 0.96 and 0.68 to 0.95 , respectively) (Figs. 3, 4). The mean allelic richness was 6.2 in Plot 1 and 6.4 in Plot 2 (ranging from 5.8 to 6.3 and 6.2 to 6.6, respectively) (Fig. 4).

Fine-scale clonal architecture $\left(1 \mathrm{~m}^{2}\right)$

Seagrass cover was 10-35\% in June 2003 and increased to $100 \%$ in all four quadrats in September 2003 (Fig. 5). In June 2004 the seagrass cover was $<1$ to $3 \%$ and $1 \%$ in September 2004 (Table 1). A total of 106 genets were identified among the 269 ramets sampled in the four subplots over the 2 year study period, but only nine were found on multiple occasions. Genet density (grand mean $\mathrm{m}^{-2}$ [SD]) was 7.6 [1.4] for the whole study period and did not significantly differ between sampling dates (Table 1). Genotypic diversity, however, was significantly lower in 2003 as compared to 2004 ( $t$ test; $p<0.001$ ) (Table 1 ). In September 2003, quadrats 2 and 3 were entirely dominated by one individual clone (Fig. 5). Both of these genets were dominant by June 2003 and also survived until September 2004. In quadrats 1 and 4, two dominant genets were encountered in 2003 and September 2004 but not detected in June 2004 (Fig. 5).

\section{Discussion}

Seagrasses have two levels of genetic variation: genetic/ allelic and genotypic/clonal (reviewed in Procaccini et al. 2007). Consequently, meadows may be genetically diverse but genotypically depauperate and vice versa. Understanding clonal architecture, therefore, provides a basis for understanding the dynamics of a seagrass bed in relation to habitat. 
Fig. 3 Large-scale clonal architecture $(10 \mathrm{~m} \times 10 \mathrm{~m})$ from May 2002 to June 2005 (M02 to J05). Clone maps of Plot 1 sorted by sampling date from top to bottom and left to right. Genotypes found multiple times are marked with numbers. Genotypes found in more than $1 \mathrm{~m}^{2}$ but only at one sampling time are marked by capital letters. Genets are framed in white for better visualization. Blank areas represent spatially and temporally unique genotypes. $\mathbf{x}$, no sample taken. Background coloring indicates seagrass cover in $\%$ for each $1 \mathrm{~m}^{2}$ from low (white) to high (black) density (see scale)
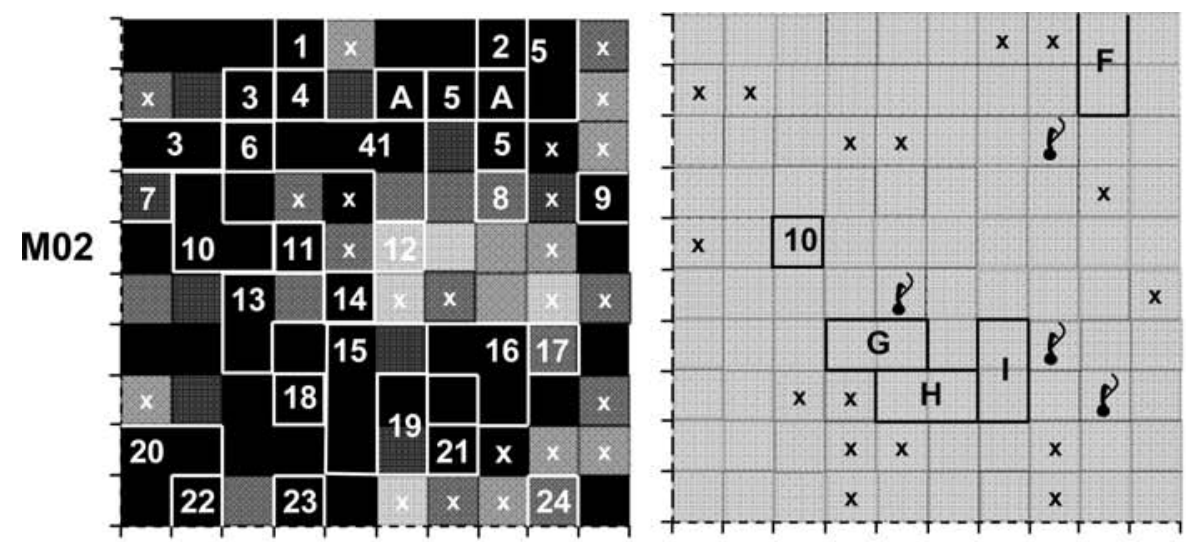

J04
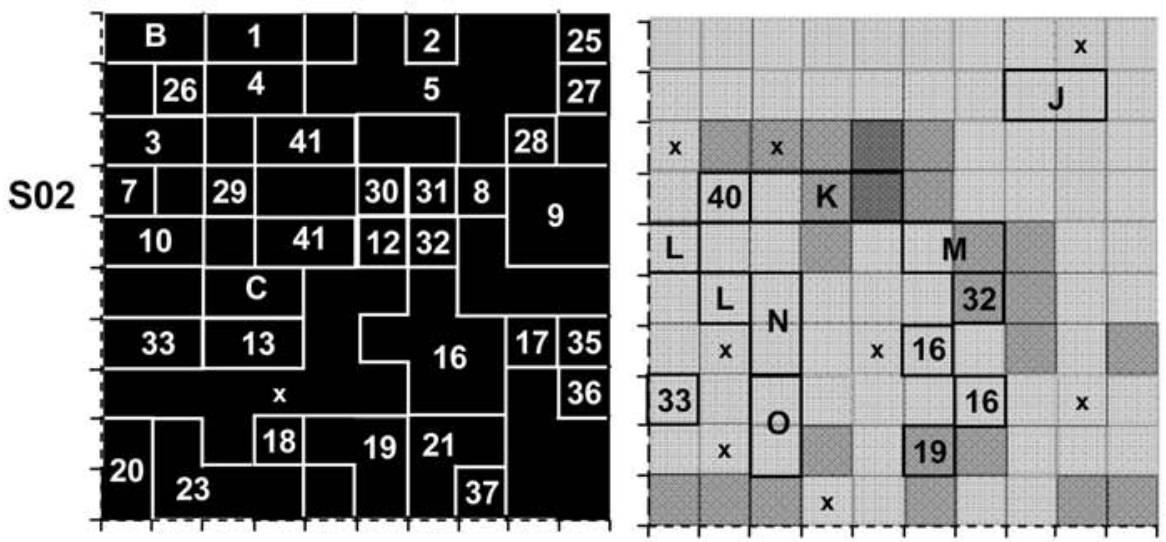

S04
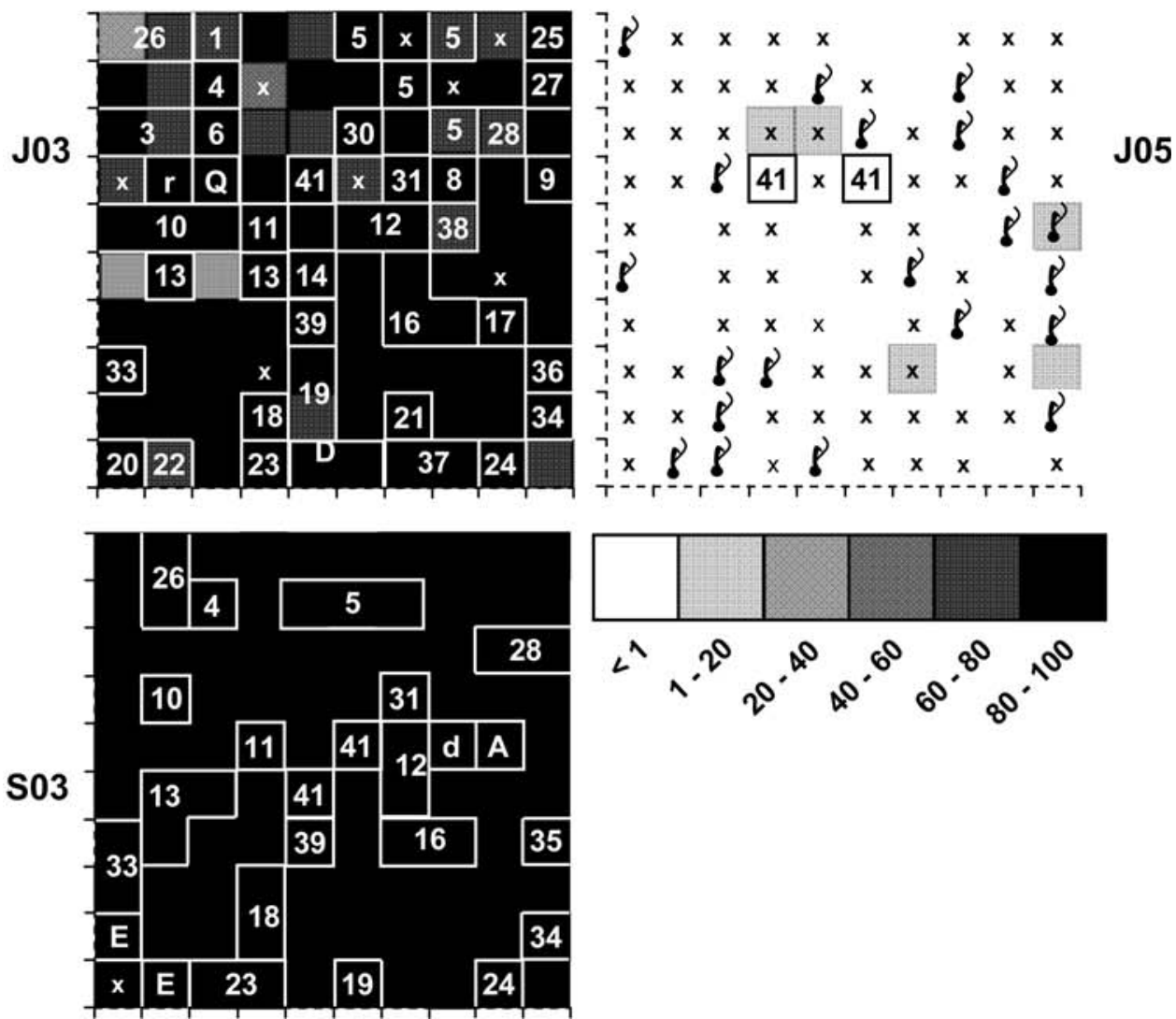

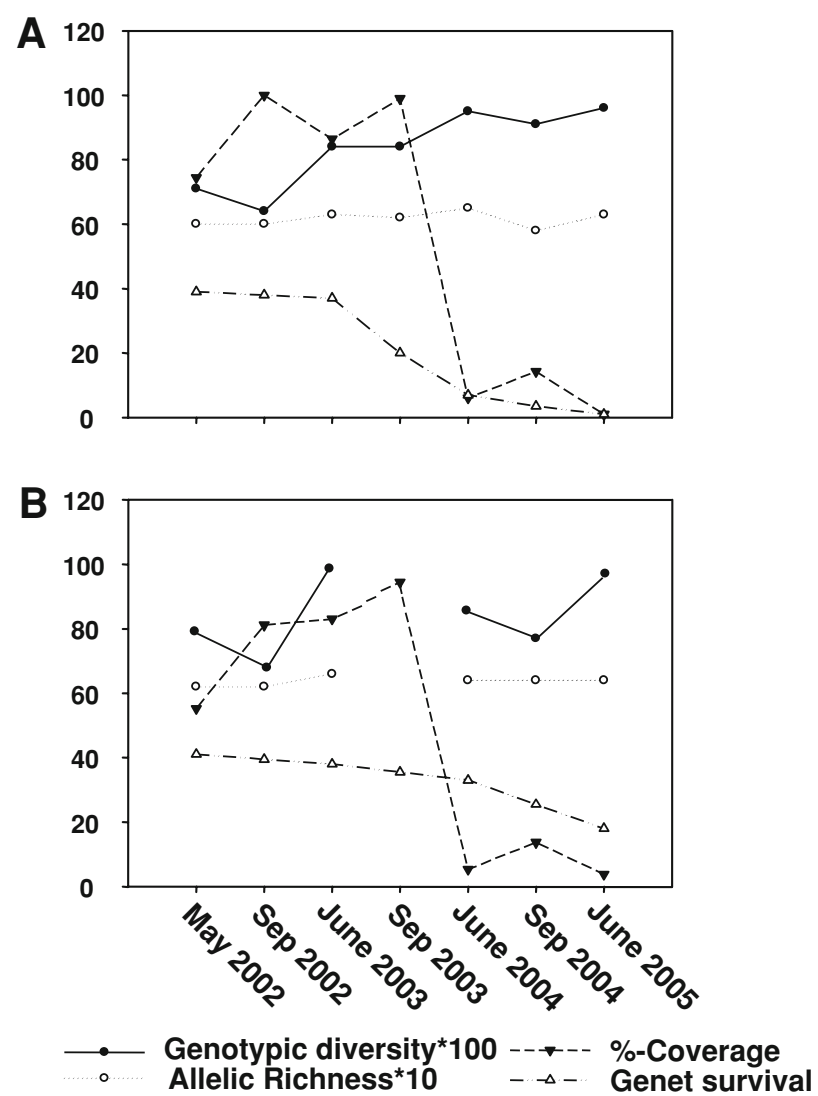

Fig. 4 Genet survival, seagrass cover, genetic and genotypic diversity in Plot 1 (a) and Plot 2 (b) for the study period (May 2002 to June 2005)

\section{Clone size and longevity}

The genet size of $Z$. noltii determined by microsatellite analysis during our 4-year study averaged $1.4 \mathrm{~m}^{2}$, and ranged from 0.04 to $9.0 \mathrm{~m}^{2}$. The genet size range is comparable to the range determined by physical excavation of whole genets and by digital image analysis of an intertidal population at Cadiz Bay in Spain $\left(0.04-4.0 \mathrm{~m}^{2}\right.$ ) (Brun et al. 2007). The largest clone in Brun et al. (2007) measured $5 \mathrm{~m}$ in length, a size attainable in 8 months based on internode production along the main axis and apical dominance, but requiring 7 years based on an average rhizome elongation rate of $0.68 \mathrm{~m} \mathrm{year}^{-1}$ (Marbà and Duarte 1998). In the present study, most clones detected on the large-scale persisted for 2-3 years, although $\sim 20 \%$ of them were present throughout our 4-year study suggesting that genet age was not correlated with size in the intertidal. Decades-old clones of $Z$. noltii, however, have been reported from the shallow subtidal in the Black and Azov Seas, and genet size may be a better proxy for genet age under less disturbed subtidal conditions (Coyer et al. 2004a). For example, each of five $1 \times 3 \mathrm{~m}$ subtidal plots of $Z$. noltii off Ischia (Naples, Italy) was densely covered by only two genets and a fragmented clone extended almost $60 \mathrm{~m}^{2}$ with an estimated age of 14.7 years (Ruggiero et al. 2005a).

Genet persistence and size positively correlated in $Z$. noltii on the fine-scale, as clones with $>50 \%$ cover at the beginning of the growing season were competitively dominant and persisted for at least 2 years (Fig. 5). The large, early-season clones undoubtedly arose from vegetative growth of overwintering rhizomes of fragmented clones. Although seedlings generally appear a month before (late April/early May) the start of vegetative propagation of the overwintering, shoot bearing rhizomes (late May/early June) (Vermaat and Verhagen 1996; Zipperle et al. 2009), subsequent vegetative growth of seedlings is not sufficient to outcompete overwintering clones by June (personal observation, Fig. 2).

Genet size of intertidal and annual populations of the sister species Z. marina rarely exceeded $0.01 \mathrm{~m}^{2}$, while in some subtidal and perennial populations, genets can extend for hundreds of $\mathrm{m}^{2}$ (Reusch et al. 1999; Olsen et al. 2004; Coyer et al. 2008) and persist for hundreds or even thousands of years (Reusch et al. 1999; Olsen et al. 2004). An emerging pattern for both Z. noltii and Z. marina, therefore, may be that clone size and longevity range from small and short-lived in the intertidal to large and long-lived in the subtidal, and are further influenced by a sliding scale of annual to perennial lifestyles. The changes of clone size and longevity from intertidal to subtidal also suggest that habitat characteristics shape the clonal architecture of Zostera species along a stress and disturbance gradient (e.g., from benign subtidal to harsh intertidal conditions), which ultimately cause a switch from a perennial to an annual lifestyle as an adaptation to stochastic environmental changes (Hu et al. 2003).

\section{Genetic diversity}

Allelic and genotypic (clonal) diversity remained high and stable throughout the study in spite of a $99 \%$ loss in aerial cover and number of genets in the large-scale plots from 2003 to 2004 (Fig. 4). As has been documented elsewhere (Coyer et al. 2004a), allelic and genotypic diversity of Z. noltii for Wadden Sea populations are among the highest recorded throughout its range and connectivity among meadows also is generally high (also for $Z$. marina; Reusch 2002; Ferber et al. 2008). At our Königshafen site, the high diversity was attributed to a combination of local and regional processes. On the larger Wadden Sea scale, entrainment and admixture of rafting, fruiting shoots and spathes are the basis for seed import, and hence population connectivity and gene flow (Coyer et al. 2004a; Erftemeijer et al. 2008; Zipperle et al., unpublished). However, finescale clonal diversity increased from 2003 to 2004, suggesting the scale-dependence of $R$ and the necessity to 
Fig. 5 Fine-scale clonal architecture of subplots $\left(1 \mathrm{~m}^{2}\right)$ within Plot 1 from June 2003 to September 2004. Clone maps of subplots 1-4 are shown from left to right and temporally sorted from top to bottom. Genotypes found on multiple sampling times are identified with letters. Genotypes found in more than one $0.2 \times 0.2$ quadrat but only on one sampling time are identified by numbers. Genets are framed in black for better visualization. Small triangles (filled triangle) indicate unique genotypes found only once in time. Light gray areas indicate bare sand
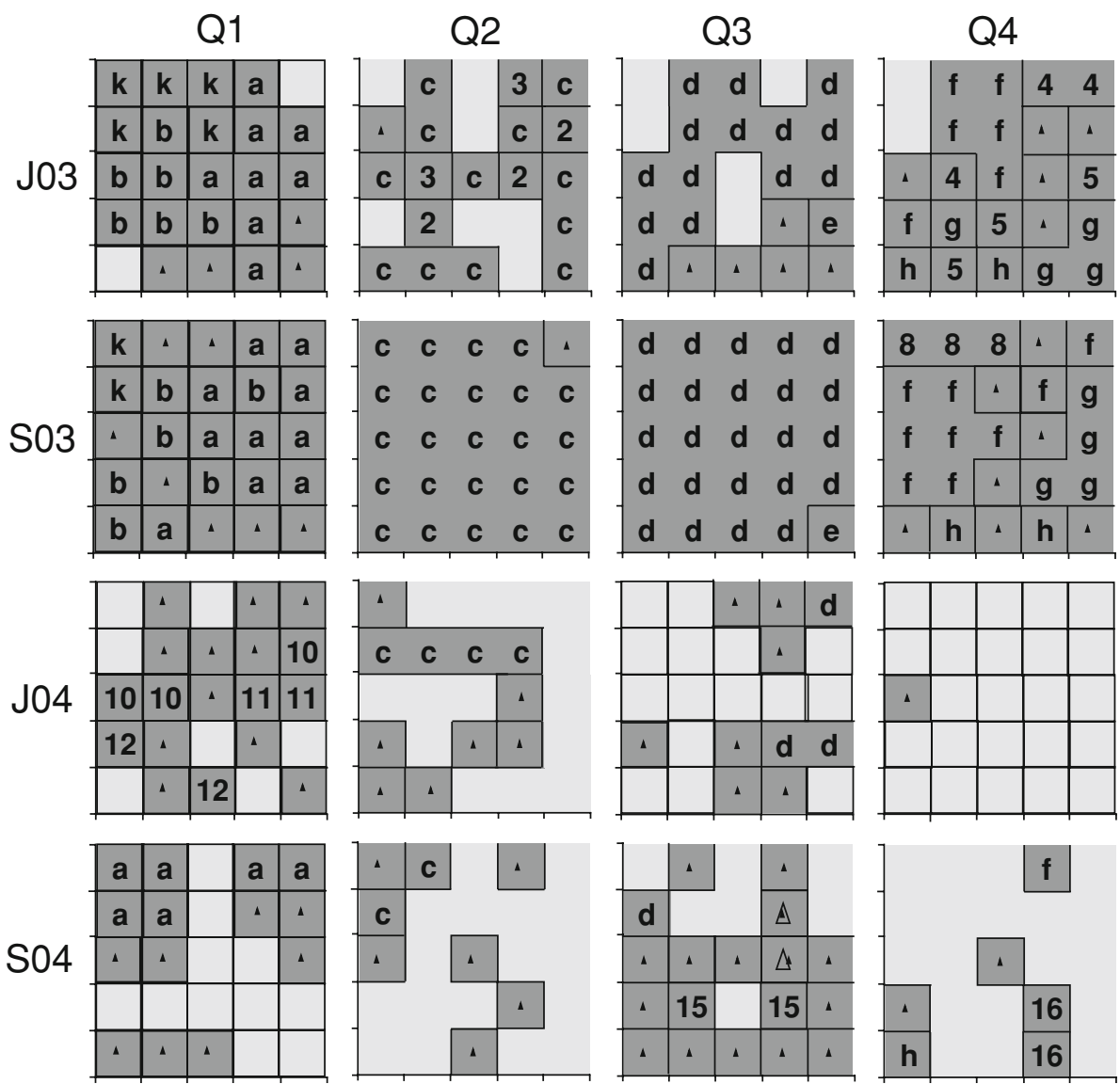

determine the appropriate scale to answer population biological questions in clonal seagrasses (Table 1). While large-scale sampling suffices to monitor population genetic parameters and stability over time in intertidal Z. noltii, assessment of demographical changes such as genet mortality and immigration requires fine-scale mapping.

The persistently high allelic and genotypic diversity observed in Königshafen suggests that disturbance plays an important role and sexual recruitment is frequent. For plants in general, stable habitats should favor vegetative reproduction and foster populations dominated by few large clones, whereas disturbed habitats should be dominated by more and smaller clones due to frequent seedling recruitment (de Steven 1989; Eriksson 1993; Kudoh et al. 1999). Disturbances by grazing waterfowl, lugworm bioturbation, epiphyte growth, and storm-induced sediment mobility, are common types of disturbances in the intertidal Wadden Sea (Jacobs et al. 1981; Reise 1985; Philippart 1994; Nacken and Reise 2000; Schanz et al. 2000; Zipperle et al., unpublished). All facilitate seedling recruitment of $Z$. noltii by creating variably sized gaps in the meadow into which recruitment can occur. Increased sexual recruitment under disturbed conditions is known for flowering plants and seagrasses (Peterken and Conacher
1997; Inglis 2000; Greve et al. 2005) and has been shown experimentally for Z. marina (Reusch 2006).

In intertidal $Z$. noltii, small clone sizes coupled with relatively large pollen dispersal distances via tidal currents, supports a predominantly outcrossing mating system, which further promotes high allelic and genotypic diversity (Zipperle, unpublished data). In contrast, large clones can lead to inbreeding depression due to pollen limitation for outcrossing, as has been shown in subtidal $Z$. marina (Hämmerli and Reusch 2003). Furthermore, as seedling recruitment substantially contributes to clonal diversity (Harada et al. 1997), it is significant that Z. noltii seedlings were observed in all June sampling periods (Zipperle, unpublished; see also Figs. 2, 3) and that seeds germinated annually from a short-term persistent seed bank (Zipperle et al. 2009). Thus, Z. noltii exhibits a repeated seedling recruitment (RSR) strategy as has been demonstrated for other seagrasses (Ruggiero et al. 2005b; Reusch 2006), as opposed to an initial seedling recruitment strategy (ISR) (sensu Eriksson 1993). Consequently, the annual losses of genets from the $Z$. noltii population in Königshafen are buffered by seedling recruitment, thereby providing the basis for the stable and high levels of genotypic diversity and allelic richness. 
Table 1 Fine-scale clonal architecture of Z. noltii

\begin{tabular}{|c|c|c|c|c|c|}
\hline & 1 & 2 & 3 & 4 & $\begin{array}{l}\text { Mean no. of } \\
\text { genets } \times \mathrm{m}^{-2}\end{array}$ \\
\hline \multicolumn{6}{|l|}{ June 2003} \\
\hline No. of ramets $(\mathrm{N})$ & 23 & 18 & 20 & 23 & \multirow{4}{*}{$7.0 \pm 2.45$} \\
\hline No. of genets $(\mathrm{G})$ & 7 & 4 & 7 & 10 & \\
\hline Genotypic diversity & 0.30 & 0.22 & 0.35 & 0.43 & \\
\hline Seagrass coverage $(\%)$ & 10 & 23 & 35 & 11 & \\
\hline \multicolumn{6}{|l|}{ Sep 2003} \\
\hline No. of ramets $(\mathrm{N})$ & 25 & 25 & 25 & 26 & \multirow{4}{*}{$6.3 \pm 4.92$} \\
\hline No. of genets $(\mathrm{G})$ & 10 & 2 & 2 & 11 & \\
\hline Genotypic diversity & 0.4 & 0.08 & 0.08 & 0.43 & \\
\hline Seagrass coverage $(\%)$ & 100 & 100 & 100 & 100 & \\
\hline \multicolumn{6}{|l|}{ June 2004} \\
\hline No. of ramets $(\mathrm{N})$ & 17 & 11 & 10 & 1 & \multirow{4}{*}{$7.8 \pm 5.32$} \\
\hline No. of genets $(\mathrm{G})$ & 14 & 8 & 8 & 1 & \\
\hline Genotypic diversity & 0.82 & 0.73 & 0.8 & 1 & \\
\hline Seagrass coverage $(\%)$ & 3 & 1 & 1 & $<1$ & \\
\hline \multicolumn{6}{|l|}{ Sep 2004} \\
\hline No. of ramets $(\mathrm{N})$ & 13 & 8 & 18 & 6 & \multirow{4}{*}{$9.5 \pm 5.26$} \\
\hline No. of genets $(\mathrm{G})$ & 9 & 7 & 17 & 5 & \\
\hline Genotypic diversity & 0.69 & 0.88 & 0.94 & 0.83 & \\
\hline Seagrass coverage $(\%)$ & 1 & 1 & 1 & 1 & \\
\hline
\end{tabular}

Number of ramets $(\mathrm{N})$ and genets $(\mathrm{G})$, genotypic diversity $(\mathrm{R}=\mathrm{G} / \mathrm{N})$ and seagrass cover $(\%)$ for the $1 \mathrm{~m}^{2}$ subplots (1-4) sorted by sampling date (top to bottom)

\section{Persistent seagrass meadow}

Although genet turnover is on the order of a few years, the intertidal Z. noltii meadow in Königshafen has been present since prior to 1936 (Reise et al. 1989; Dolch 2008; Fig. 1). The decades-long persistence in a harsh environment may be explained by the contribution of sexual reproduction and seed bank supply to meadow maintenance. The precipitous decline in seagrass cover from 2003 to 2004 in Königshafen may have been caused by enhanced sediment mobility, as revealed by characteristic megaripple formation (Fig. 1, C2 and 3) (Dolch, pers. comm.). The increased sediment mobility may be attributed to the loss of extensive $Z$. marina beds, anthropogenic alteration of the hydrodynamic regime in the List tidal basin, and/or an increase of mean tidal height due to variation in storm intensity over the last decades (Dolch and Hass 2008).

Alternatively, the 2003-2004 decrease may be due to the severe heat stress event (HSE) in the summer of 2003, which has been associated with biomass and density losses in European populations of P. oceanica, Z. marina, and Z. noltii (Mayot et al. 2005; Reusch et al. 2005; Cardoso et al. 2008). Although the decline of $\mathrm{Z}$. noltii recorded at Königshafen was correlated with the HSE, the correlation was not observed at the metapopulation scale $\left(930 \mathrm{~km}^{2}\right)$ in the North Frisian Wadden Sea, of which Königshafen is a part (Reise and Kohlus 2008). Thus, the HSE disturbance may have acted in tandem with increased sediment mobility to degrade the Königshafen meadow (local scale). Cardoso et al. (2008) invoke a comparable coupling of HSE and eutrophication stress to explain observed decreases in an intertidal $Z$. noltii bed in the Mondego river estuary (Portugual, SW Atlantic).

In spite of the biomass decline, genet survival of Z. noltii was 4-18 times higher in Plot 2 as compared to Plot 1. The edge location of Plot 1 relative to the more central location of Plot 2 might explain the difference. Wave impact and sediment mobility may be more severe at the edges of seagrass meadows than in the center where hydrodynamics are reduced and water retention is higher (Fonseca and Koehl 2006). Under heat stress, a center location may also be more suitable for survival because retained water prevents desiccation and hence mortality. However, it should be noted that intertidal Zostera populations are adapted to survive short-term desiccation (Leuschner and Rees 1993).

Percent-cover of Z. noltii remained low during 2004 and 2005. While sufficient sexual recruitment assures evolutionary flexibility in physically disturbed habitats, it may be insufficient to balance exceptionally high adult mortality (Forbis and Doak 2004; Weppler et al. 2006). A patch of $Z$. noltii in the Königshafen meadow recovered only if the overwintering cover was $>10 \%$ (at the beginning of the growing season). Because of the small genet size, a reduction in density is nearly equivalent to a reduction in total number of genets in the population. A reduced number of genets in spring, therefore, might not provide sufficient vegetative growth until the end of the growing season. If too few genets survive the winter to provide sufficient vegetative regrowth in the following season, then seedling recruitment may not balance this loss. Alternatively, an inhibition of regrowth in spring and early summer might also be caused by enhanced sediment mobility.

The importance of a short-term persistent seed bank to maintain allelic richness of $Z$. noltii has been demonstrated over a 3-year period (Zipperle et al. 2009). Possession of a seed bank should help $Z$. noltii overcome periods unfavorable for vegetative recovery, as has been demonstrated for seagrasses and other plants (Silvertown and Charlesworth 2001; Fenner and Thompson 2005; Greve et al. 2005). If seedling recruitment and subsequent vegetative growth can attain a density sufficient to exceed winter mortality of genets, the population is likely to recover even after exceptionally severe disturbances. The marked increase (up to $20 \%$ ) of $Z$. noltii cover at the Königshafen study site in August 2008 (Reise, unpublished data), 4 years after the precipitous decline, supports the self- 
preserving effects of sexual reproduction from a seed bank for $Z$. noltii in a stressful environment.

In conclusion, decadal persistence of intertidal meadows of $Z$. noltii depends on a balance of year-to-year genet survival (vegetative growth), frequent seedling recruitment (sexual reproduction), and a lasting seed bank. This is in sharp contrast to larger seagrass species, where meadow persistence over centuries involves extensive vegetative propagation (Posidonia species, subtidal Z. marina) or to subtidal $Z$. noltii meadows, where vegetative propagation dominates and recruitment from seeds is rare (Laugier et al. 1999; Ruggiero et al. 2005a, b). While seedling recruitment ensures evolutionary flexibility in face of environmental stochasticity and annual disturbances, vegetative growth of overwintering ramets promotes recovery after winter mortality. An assessment of these two factors provides a metric for predicting patch vulnerability in the intertidal.

Acknowledgments We thank S. Ferber, E. Boon and A. Matthäi for field assistance and J. Veldsink for laboratory assistance. G. Hoarau and M. Chevolot provided helpful comments for data analysis and T. Dolch clarified our understanding of sediment dynamics at Königshafen. This research was supported by an Ubbo Emmius $\mathrm{PhD}$ stipend from the University of Groningen to AMZ.

Open Access This article is distributed under the terms of the Creative Commons Attribution Noncommercial License which permits any noncommercial use, distribution, and reproduction in any medium, provided the original author(s) and source are credited.

\section{References}

Arnaud-Haond S, Belkhir K (2007) GENCLONE: a computer program to analyze genotypic data, test for clonality and describe spatial clonal organization. Mol Ecol Notes 7:15-17

Arnaud-Haond S, Alberto F, Teixeira S, Procaccini G, Serrão EA, Duarte CM (2005) Assessing genetic diversity in clonal organisms: low diversity or low resolution? Combining power and cost efficiency in selecting markers. J Hered 96:434-440

Arnaud-Haond S, Duarte CM, Alberto F, Serrão EA (2007) Standardizing methods to address clonality in population studies. Mol Ecol 16:5115-5139

Barrett SCH, Harder LD (1996) Ecology and evolution of plant mating. Trends Ecol Evol 11:73-79

Barrett LG, He TH, Lamont BB, Krauss SL (2005) Temporal patterns of genetic variation across a 9-year-old aerial seed bank of the shrub Banksia hookeriana (Proteaceae). Mol Ecol 14:4169-4179

Brun FG, Pérez-Pastor A, Hernández I, Vergara JJ, Pèrez-Lloréns JL (2006) Shoot organization in the seagrass Zostera noltii: implications for space occupation and plant architecture. Helgol Mar Res 60:59-69

Brun FG, Cummaudo F, Olivé I, Vergara JJ, Perez-Lloréns JL (2007) Clonal extent, apical dominance and networking features in the phalanx angiosperm Zostera noltii Hornem. Mar Biol 151:19171927

Cabaço S, Santos R (2007) Effects of burial and erosion on the seagrass Zostera noltii. J Exp Mar Biol Ecol 34:204-212
Cardoso PG, Raffaeli D, Pardal MA (2008) The impact of extreme weather events on the seagrass Zostera noltii and related Hydrobia ulvae population. Mar Poll Bull 56:483-492

Charpentier A (2001) Consequences of clonal growth for plant mating. Evol Ecol 5:521-530

Coyer JA, Diekmann OE, Serrão EA, Procaccini G, Milchakova N, Pearson GA, Stam WT, Olsen JL (2004a) Population genetics of dwarf eelgrass Zostera nolti throughout its biogeographic range. Mar Ecol-Prog Ser 281:51-62

Coyer JA, Reusch TBH, Stam WT, Serrão EA, Pearson G, Procaccini G, Olsen JL (2004b) Characterization of microsatellite loci in the dwarf eelgrass Zostera noltii (Zosteraceae) and cross-reactivity with Z. japonica. Mol Ecol Notes 4:497-499

Coyer JA, Miller KA, Engle JM, Veldsink J, Cabello-Pasini A, Stam WT, Olsen JL (2008) Eelgrass meadows in the California Channel Islands and adjacent coast reveal a mosaic of two species, evidence for introgression and variable clonality. Ann Bot 101:73-87

de Steven D (1989) Genet and ramet demography of Oenocarpus mapora ssp. mapora, a clonal palm of Panamanian. Trop Moist Forest 77:579-596

den Hartog C (1970) The seagrasses of the World. North Holland Publishing Company, Amsterdam $275 \mathrm{p}$

Dolch T (2008) High-resolution spatial analysis of morphodynamics and habitat changes in the Wadden Sea (SE North Sea). PhD Thesis, Christian-Albrecht-Universität Kiel

Dolch T, Hass HC (2008) Long-term changes of intertidal and subtidal sediment compositions in a tidal basin in the northern Wadden Sea (SE North Sea). Helgol Mar Res 62:3-11

Ellstrand NC, Elam DR (1993) Population genetic consequences of small population size: implications for plant conservation. Ann Rev Ecol Syst 24:217-243

Elphinstone M, Hinten G, Anderson M, Nock C (2003) An inexpensive and high-throughput procedure to extract and purify total genomic DNA for population studies. Mol Ecol Notes 3:317-320

Erftemeijer PLA, van Beek JKL, Ochieng CA, Jager Z, Los HJ (2008) Eelgrass seed dispersal via floating generative shoots in the Dutch Wadden Sea: a model approach. Mar Ecol-Prog Ser 358:115-124

Eriksson O (1993) Dynamics of genets in clonal plants. Trends Ecol Evol 8:313-316

Fenner M, Thompson K (2005) The ecology of seeds. University Press Cambridge, Cambridge

Ferber S, Stam WT, Olsen JL (2008) Genetic diversity and connectivity remain high in eelgrass (Zostera marina) populations in the Wadden Sea despite major impacts. Mar Ecol-Prog Ser 372:87-96

Fonseca MS, Koehl MAR (2006) Flow in seagrass canopies: the influence of patch width. Est Coast Shelf Sci 67:1-9

Forbis TA, Doak DF (2004) Seedling establishment and life history trade-offs in alpine plants. Am J Bot 91:1147-1153

Greve TM, Krause-Jensen D, Rasmussen MB, Christensen PB (2005) Means of rapid eelgrass (Zostera marina L.) recolonization in former dieback areas. Aquat Bot 82:143-156

Hämmerli A, Reusch TBH (2002) Local adaptation and transplant dominance in genets of the marine clonal plant Zostera marina. Mar Ecol-Prog Ser 242:111-118

Hämmerli A, Reusch TBH (2003) Inbreeding depression influences genet size distribution in a marine angiosperm. Mol Ecol 12(3):619-629

Harada Y, Kawano S, Iwasa Y (1997) Probability of clonal identity: inferring the relative success of sexual versus clonal reproduction from spatial genetic patterns. J Ecol 85:591-600

Harper JL (1977) Population biology of plants. Academic Press, London 
Hemminga MA, Duarte CM (2000) Seagrass ecology. Cambridge University Press, Cambridge

Hootsmans MJM, Vermaat JE, Vanvierssen W (1987) Seed-Bank development, germination and early seedling survival of two seagrass species from the Netherlands-Zostera marina L. and Zostera noltii Hornem. Aquat Bot 28:275-285 382

Hu FY, Tao DY, Sacks E, Fu BY, Xu P, Li J et al (2003) Convergent evolution of perenniality in rice and sorghum. Proc Nat Acad Sci USA 100:4050-4054

Inglis GJ (2000) Disturbance-related heterogeneity in the seed banks of a marine angiosperm. J Ecol 88:88-99

Jacobs RPWM, den Hartog C, Braster BF, Carriere FC (1981) Grazing of the seagrass Zostera noltii by birds at Terschelling (Dutch Wadden Sea). Aquat Bot 10:241-259

Koch M, Huthmann M, Bernhardt KG (2003) Cardamine amara L. (Brassicaceae) in dynamic habitats: genetic composition and diversity of seed bank and established populations. Basic Appl Ecol 4:339-348

Kudoh H, Shibaike H, Takasu H, Whigham DF, Kawado S (1999) Genet structure and determinants clonal structure in a temperate deciduous woodland herb, Uvularia perfoliata. J Ecol 87:244257

Laugier T, Rigollet V, de Casabianca ML (1999) Seasonal dynamics in mixed eelgrass beds, Zostera marina L. and Zostera noltii Hornem., in a Mediterranean coastal lagoon (Thau lagoon, France). Aquat Bot 63:51-69

Leuschner C, Rees U (1993) CO2 gas exchange of two intertidal seagrass species, Zostera marina L. and Zostera noltii Hornem., during emersion. Aquat Bot 45:53-62

Marbà N, Duarte CM (1998) Rhizome elongation and seagrass clonal growth. Mar Ecol-Prog Ser 174:269-280

Mayot N, Boudouresque CF, Leriche A (2005) Unexpected response of the seagrass Posidonia oceanica to a warm water episode in the North Western Mediterranean Sea. C R Biol 328:291-296

Nacken M, Reise K (2000) Effects of herbivorous birds on intertidal seagrass beds in the northern Wadden Sea. Helgol Mar Res 54:87-94

Nienburg W (1927) Zur Ökologie der Flora des Wattenmeeres. I. Der Königshafen bei List auf Sylt. Wiss Meeresunters Kiel 20:146196

Olsen JL, Stam WT, Coyer JA, Reusch BHT, Billingham M, Boström C, Calvert E, Christie H, Granger S, La Lumiere R, Milchakova N, le Secq-Oudot MS, Procaccini G, Sanjabi B, Serrão E, Veldsink JH, Widdicombe S, Wyllie-Echeverria S (2004) North Atlantic phylogeography and large-scale population differentiation of the seagrass Zostera marina L. Mol Ecol 13:1923-1941

Orth RJ, Luckenbach M, Moore KA (1994) Seed dispersal in a marine macrophyte-implications for colonization and restoration. Ecology 75:1927-1939

Peterken CJ, Conacher CA (1997) Seed germination and recolonisation of Zostera capricorni after grazing by dugongs. Aquat Bot 59:333-340

Philippart CJM (1994) Interactions between Arenicola marina and Zostera noltii on a tidal flat in the Wadden Sea. Mar Ecol-Prog Ser 111:251-257

Philippart CJM, Dijkema KS (1995) Wax and wane of Zostera noltii Hornem. in the Dutch Wadden Sea. Aquat Bot 49:255-268

Procaccini G, Olsen JL, Reusch TBH (2007) Contribution of genetics and genomics to seagrass biology and conservation. J Exp Mar Biol Ecol 350:234-259

Reise K (1985) Tidal flat ecology-an experimental approach to species interactions. Springer Verlag, Berlin
Reise K, Kohlus J (2008) Seagrass recovery in the Northern Wadden Sea? Helgol Mar Res 62:77-84

Reise K, Herre E, Sturm M (1989) Historical changes in the benthos of the Wadden Sea around the island of Sylt in the North Sea. Helgol Meeresunters 43:417-433

Reusch TBH (2001a) Fitness-consequences of geitonogamous selfing in a clonal marine angiosperm (Zostera marina). J Evol Biol 14:129-138

Reusch TBH (2001b) New markers-old questions: population genetics of seagrasses. Mar Ecol-Prog Ser 211:261-274

Reusch TBH (2002) Microsatellites reveal high population connectivity in eelgrass (Zostera marina) in two contrasting coastal areas. Limnol Oceanogr 47:78-85

Reusch TBH (2006) Does disturbance enhance genotypic diversity in clonal organisms? A field test in the marine angiosperm Zostera marina. Mol Ecol 15:277-286

Reusch TBH, Boström C, Stam WT, Olsen JL (1999) An ancient eelgrass clone in the Baltic. Mar Ecol-Prog Ser 183:301-304

Reusch TBH, Ehlers A, Hämmerli A, Worm B (2005) Ecosystem recovery after climatic extremes enhanced by genotypic diversity. Proc Natl Acad Sci USA 102:2826-2831

Ruckelshaus MJ (1996) Estimation of genetic neighborhood parameters from pollen and seed dispersal in the marine angiosperm Zostera marina L. Evolution 50:856-864

Ruggiero MV, Turk R, Procaccini G (2002) Genetic identity and homozygosity in North-Adriatic populations of Posidonia oceanica: an ancient, post-glacial clone? Conserv Genet 3:71-74

Ruggiero MV, Capone S, Pirozzi P, Reusch TBH, Procaccini G (2005a) Mating system and clonal architecture: a comparative study in two marine angiosperms. Evol Ecol 19:487-499

Ruggiero MV, Reusch TBH, Procaccini G (2005b) Local genetic structure in a clonal dioecious angiosperm. Mol Ecol 14:957967

Schanz A, Asmus H (2003) Impact of hydrodynamics on the development and morphology of intertidal seagrasses in the Wadden Sea. Mar Ecol-Prog Ser 261:123-134

Schanz A, Polte P, Asmus H, Asmus R (2000) Currents and turbulance as top down regulator in intertidal seagrass communities. Biol Mar Medit 7:278-281

Silvertown J, Charlesworth D (2001) Introduction to plant population biology. Blackwell Publishing, Oxford

Vermaat JE, Verhagen FCA (1996) Seasonal variation in the intertidal seagrass Zostera noltii Hornem.: coupling demographic and physiological patterns. Aquat Bot 52:259-281

Waycott M (1995) Assessment of genetic variation and clonality in the seagrass Posidonia australis using RAPD and allozyme analysis. Mar Ecol-Prog Ser 116:289-295

Waycott M, Procaccini G, Les DH, Reusch TBH (2006) Seagrass evolution, ecology and conservation: a genetic perspective. In: Larkum WD, Orth RJ, Duarte CM (eds) Seagrasses: biology, ecology and conservation. Springer, Dordrecht, pp 25-50

Weppler T, Stoll P, Stocklin J (2006) The relative importance of sexual and clonal reproduction for population growth in the long-lived alpine plant Geum reptans. J Ecol 94:869-879

Wohlenberg E (1935) Beobachtungen über das Seegras Zostera marina L. und seine Erkrankung im nordfriesischen Wattenmeer. Beiträge zur Heimatforschung in Schleswig-Holstein, Hamburg Lübeck 11:1-19

Zipperle AM, Coyer JA, Reise K, Stam WT, Olsen JL (2009) Evidence for persistent seed banks in dwarf eelgrass Zostera noltii in the German Wadden Sea. Mar Ecol-Prog Ser 380:73-80 